\title{
Correction: Frequent traces of EBV infection in Hodgkin and non-Hodgkin lymphomas classified as EBV-negative by routine methods: expanding the landscape of EBV-related lymphomas
}

\author{
Lucia Mundo - Leonardo Del Porro - Massimo Granai - Maria Chiara Siciliano - Virginia Mancini - Raffaella Santi • \\ Lynnette Marcar · Katerina Vrzalikova · Federica Vergoni - Gioia Di Stefano · Gianluca Schiavoni • \\ Giovanna Segreto · Noel Onyango · Joshua Akelo Nyagol · Teresa Amato · Cristiana Bellan · \\ loannis Anagnostopoulos • Brunangelo Falini · Lorenzo Leoncini · Enrico Tiacci · Stefano Lazzi
}

Published online: 29 June 2020

(c) The Author(s) 2020. This article is published with open access

Correction to: Modern Pathology https://doi.org/10.1038/s41379-020-0575-3

The article Frequent traces of EBV infection in Hodgkin and non-Hodgkin lymphomas classified as EBV-negative by routine methods: expanding the landscape of EBV-related lymphomas was originally published electronically on the publisher's internet portal on 1st June 2020 without open access. With the authors' decision to opt for Open Choice the copyright of the article changed to (c) The Author(s) 2020 and the article is forthwith distributed under a Creative Commons Attribution 4.0 International License (https://crea tivecommons.org/licenses/by/4.0/), which permits use, sharing, adaptation, distribution and reproduction in any medium or format, as long as you give appropriate credit to the original author(s) and the source, provide a link to the Creative Commons licence, and indicate if changes were made.

Open Access This article is licensed under a Creative Commons Attribution 4.0 International License, which permits use, sharing, adaptation, distribution and reproduction in any medium or format, as long as you give appropriate credit to the original author(s) and the source, provide a link to the Creative Commons license, and indicate if changes were made. The images or other third party material in this article are included in the article's Creative Commons license, unless indicated otherwise in a credit line to the material. If material is not included in the article's Creative Commons license and your intended use is not permitted by statutory regulation or exceeds the permitted use, you will need to obtain permission directly from the copyright holder. To view a copy of this license, visit http://creativecommons. org/licenses/by/4.0/. 